\title{
Summary of recommendations on malaria issues in special hosts
}

by the Committee to Advise on Tropical Medicine and Travel (CATMAT)

Boggild $\mathrm{A}^{1}$, Brophy $\mathrm{J}^{2}$, Charlebois $\mathrm{P}^{3}$, Crockett $\mathrm{M}^{4}$, Geduld $\mathrm{J}^{5}$, Ghesquiere $\mathbf{W}^{6}$, McDonald $\mathrm{P}^{7}$, Plourde $\mathrm{P}^{8}$, Teitelbaum $\mathrm{P}^{9}$, Tepper $\mathrm{M}^{10}$, Schofield $\mathrm{S}^{11}$ and McCarthy $\mathrm{A}$ (Chair) ${ }^{12_{*}}$

1 University Health Network, Toronto General Hospital, Toronto, Ontario

2 Division of Infectious Diseases, Children's Hospital of Eastern Ontario, Ottawa, Ontario

3 Internal Medicine, Canadian Forces Health Services Centre (Atlantic), Halifax, Nova Scotia

4 Paediatrics and Child Health, University of Manitoba, Winnipeg, Manitoba

5 Infectious Disease Prevention and Control Branch, Public Health Agency of Canada, Ottawa, Ontario

6 Infectious Diseases and Internal Medicine, University of British Columbia, Victoria, British Columbia

7 Therapeutic Products Directorate, Health Canada, Ottawa, Ontario

8 Faculty of Medicine, University of Manitoba, Winnipeg, Manitoba

9 Riverside Travel Medicine Clinic, Ottawa, Ontario

${ }^{10}$ Communicable Disease Control Program, Directorate of Force Health Protection (Ottawa, Ontario)

${ }^{11}$ Pest Management Entomology, Directorate of Force Health Protection, Ottawa, Ontario

${ }^{12}$ Tropical Medicine and International Health Clinic, Division of Infectious Disease, Ottawa Hospital General Campus, Ottawa, Ontario

Corresponding author: AMcCARTHY@Ottawahospital.on.ca

\section{Abstract}

Background: On behalf of the Public Health Agency of Canada, the Committee to Advise on Tropical Medicine and Travel (CATMAT) developed the Canadian Recommendations for the Prevention and Treatment of Malaria Among International Travellers for Canadian health care providers who are preparing patients for travel to malaria-endemic areas and treating travellers who have returned ill.

Objective: To provide guidelines on malaria issues related to special hosts.

Methods: CATMAT reviewed all major sources of information on malaria prevention, as well as recent research and national and international epidemiological data, to tailor guidelines to the Canadian context. The evidence-based medicine recommendations were developed with associated rating scales for the strength and quality of the evidence.

Recommendations: All people visiting malaria endemic regions should use effective personal protective measures (PPM; topical repellants, bed nets, behavioural choices) and the prescribed chemoprophylaxis. Chemoprophylaxis for pregnant and breastfeeding women and for children requires careful consideration in the context of the pregnancy trimester, the age or size of the infant/child as well as their glucose-6phosphate dehydrogenase (G6PD) status. Recommendations for long-term travellers, expatriates and people visiting friends and relatives (VFRs) do not differ markedly from those for short-term travellers. Some underlying medical conditions may make individuals more vulnerable to malaria. In addition, some conditions or their treatment may preclude the use of one or more antimalarial medications. 


\section{Introduction}

Malaria is a serious infection caused by five different species of the genus Plasmodium: falciparum, vivax, ovale, malariae and knowlesi. Malaria is transmitted by the bite of infected female anopheline mosquitoes. Infections caused by $P$. falciparum have the highest fatality rates. The overall case-fatality rate of falciparum malaria varies from about $1 \%$ to $5 \%$ and increases to $20 \%$ for those with severe malaria (1).

The Committee to Advise on Tropical Medicine and Travel (CATMAT) provides the Public Health Agency of Canada with ongoing and timely medical, scientific and public health advice relating to tropical disease and health risks associated with international travel. This is a summary of one section of the CATMAT Canadian Recommendations for the Prevention and Treatment of Malaria Among International Travellers developed for Canadian health care providers who are preparing patients for travel to malaria-endemic areas and treating travellers who have returned ill (2). These guidelines include a full description of the recommendations on risk assessment, prevention and treatment of malaria, a disease that is still uncommon in Canada. Two additional summaries of the guidelines are available focusing on prevention and treatment of malaria $(3,4)$.

Special groups of travellers have different risks of acquiring malaria infection compared with the average traveller. If unable to defer travel to areas with high risk of malaria, pregnant and breastfeeding women and small children should receive tailored antimalarial chemoprophylaxis, since some of the drugs are contraindicated in these groups. Long-term travellers, expatriates and travellers visiting friends and relatives (VFRs) may perceive malaria risk differently and may adhere differently to chemoprophylaxis. They require additional information about self-diagnosis and treatment. The issue of counterfeit drugs is addressed specifically for long-term travellers

\section{Methods}

The Malaria Subcommittee, a working group of CATMAT, developed the guidelines. The process undertaken to develop them has been described previously (3). It included a review of recent research and national and international epidemiological data, and the consideration of other factors, such as malaria epidemiology, and the anticipated values and preferences of travellers and health care providers. The evidence-based medicine recommendations for various malaria issues pertaining to special hosts were developed with associated rating scales for the strength and quality of the evidence.

\section{Recommendations}

The evidence-based CATMAT recommendations for malaria prevention and treatment in special hosts are summarized in Table 1. A discussion of some of the key recommendations follows.

\section{Children}

Malaria disproportionately affects children and can have nonspecific symptoms that mimic other common childhood illnesses, leading to delays in diagnosis. Severe or complicated malaria, such as cerebral malaria, severe anemia, shock or even death, may develop more quickly in children (5).

Young children should avoid travel to areas with significant malaria transmission, particularly of chloroquineresistant malaria (6). When travel to malaria-endemic areas is unavoidable consider the following:

- All children should use effective personal protective measures (PPM: topical repellants, bed nets, behavioural choices) (7) and appropriate malaria chemoprophylaxis $(1,8)$.

- For chloroquine-resistant areas, mefloquine, doxycycline (for those $\geq 8$ years) and atovaquone-proguanil $(\geq 5 \mathrm{~kg})$ are most appropriate $(9-12)$

- Primaquine may be suitable for children who are unable to take the first-line prophylactic agents, once adequate G6PD (glucose-6-phosphate dehydrogenase) levels have been confirmed (13).

- Prescribe antimalarial drugs for breastfeeding infants even if their mother is taking antimalarials $(6,14)$.

- Specific instructions related to dosing: 
Prescribe sufficient tablets to allow a few doses to be vomited or spat out. Give clear instructions when to repeat doses that were not successfully ingested;

Have tablets pre-cut or crushed and inserted into capsules to increase the accuracy and ease of dosing;

- Describe how to adjust the dose of medications to allow for an increase in children's weight.

- Explain that because there are few pediatric formulations, malaria tablets may be crushed and mixed with something sweet to disguise their unpleasant taste.

\section{Pregnant and breastfeeding women}

Pregnant women should defer travel to malaria-endemic areas and particularly to regions with drug-resistant falciparum malaria (15). Malaria increases the risk of maternal and neonatal death, miscarriage and stillbirth. Low birth-weight infants are more commonly born to women taking ineffective prophylaxis (15).

If travel is unavoidable,

- Pregnant and breastfeeding women should use PPM (topical repellents, insecticide-treated bed nets, and behavioural choices) (16).

- Prescribe chemoprophylaxis based on destination:

- Chloroquine in chloroquine-sensitive areas;

Mefloquine where exposure to chloroquine-resistant falciparum malaria is unavoidable (17-19);

Discuss the benefits and risks of atovaquone-proguanil after the first trimester in women who cannot avoid travel to mefloquine-resistant areas or who cannot take mefloquine $(20,21)$;

- Although safe in pregnancy, the combination of chloroquine and proguanil is inadequate as an antimalarial and cannot be recommended for chloroquine-resistant areas (22);

- Doxycycline is contraindicated during pregnancy.

Nursing women should continue to breastfeed if using chemoprophylaxis that is safe in infancy (chloroquine, mefloquine, atovaquone-proguanil in infants weighing $\geq 5 \mathrm{~kg}$ ). Doxycycline absorption through breast milk is probably negligible, and breastfeeding is not an absolute contraindication to maternal use (23).

\section{Migrants}

Although in most cases disease will develop within three months of last exposure, malaria could be the reason for any fever that develops within 12 months of leaving a malaria-endemic region (24). The risk of malaria exists for migrants after their arrival in Canada:

- For at least 12 months after migrants arrive in Canada, test for malaria in cases of unexplained fever.

- Consider malaria screening in asymptomatic new migrants from highly endemic areas, and treat those with parasitemia (apart from the presence of gametocytes only) in blood smears.

- Ask migrants from malaria-endemic countries about future travel plans to provide anticipatory guidance about malaria (25).

\section{Long-term travellers, expatriates and visiting friends and relatives}

Recommendations for preventing malaria in long-term travellers (travel for longer than one month), expatriates or visiting friends and relatives are very similar to the standard recommendations for the short-term traveller (26): use prescribed malaria chemoprohylaxis and PPM consistently, including insecticide-treated bed nets and topical repellents containing $20 \%-30 \%$ DEET or $20 \%$ icaridin.

Some of the topics to cover when counselling expatriates and long-term travellers about malaria prevention include the following:

- Possible concern about safety with prolonged use of chemoprophylaxis medication.

- Use of PPM over the long term.

- Cost of medication over the long term. 
- Use of locally procured and possibly counterfeit drugs.

- Conflicting counsel about chemoprophylaxis and self-treatment.

- Need for ongoing adherence to chemoprophylaxis.

Since overall nonadherence rates for chemoprophylaxis are as high as $61 \%(27)$, pre-travel advice should focus on these aspects:

- Malaria symptoms and risk, emphasizing the need for early diagnosis and treatment.

- Development of a plan for accessing competent medical care in case of illness.

- Standby emergency therapy (self-treatment).

- The affordability of chemoprophylaxis.

- The likelihood that local malaria drugs are counterfeit (28).

- The loss of partial immunity among visiting friends and relatives because of residence in a country without malaria (25).

The risk of malaria among visiting friends and relatives is almost the same as for local residents, but the risk of severe disease is higher because of loss of partial immunity after having lived in a non-endemic area (25).

VFRs tend to show certain characteristics:

- Be less likely to seek out or comply with preventive travel health advice (29-31), possibly because of

Financial or time restrictions (25);

Misconceptions about risk of disease and immunity; or

Reliance on advice from family members or local providers at their destination $(25,27,28,32,33)$.

- Stay in rural locations (with higher rates of malaria transmission than urban centres) and for longer visits (25).

- Stay with local family members rather than in air-conditioned and well-screened hotels (25).

- Travel with their Canadian-born children (25).

- Make last-minute emergency travel plans (25).

Table 1: Evidence-based medicine recommendations for malaria prevention and treatment in special hosts

\begin{tabular}{|c|c|c|}
\hline \multicolumn{2}{|c|}{ Recommendation } & $\begin{array}{l}\text { EBM } \\
\text { rating* }\end{array}$ \\
\hline \multicolumn{3}{|c|}{ Children } \\
\hline 1. & $\begin{array}{l}\text { Young children should avoid travel to areas with significant malaria transmission, particularly of } \\
\text { chloroquine-resistant malaria (6). }\end{array}$ & C III \\
\hline 2. & All children who travel to malaria-endemic areas should use PPM (7). & A I \\
\hline 3. & $\begin{array}{l}\text { In chloroquine-resistant areas, mefloquine, doxycycline ( } \geq 8 \text { years) and atovaquone-proguanil }(\geq 5 \\
\mathrm{kg}) \text { are the drugs of choice for chemoprophylaxis }(9-12) .\end{array}$ & A I \\
\hline 4. & $\begin{array}{l}\text { Primaquine chemoprophylaxis may be suitable for children who cannot take any of the first-line } \\
\text { prophylactic agents, after confirmation of G6PD status (13). }\end{array}$ & B II \\
\hline \multicolumn{3}{|c|}{ Pregnant women } \\
\hline 5. & Pregnant women should avoid travel to areas with significant malaria transmission (15). & C III \\
\hline 6. & $\begin{array}{l}\text { Pregnant women who travel to malaria-endemic areas should use PPM, including appropriate } \\
\text { topical repellents and insecticide-treated bed nets }(16) .\end{array}$ & Al \\
\hline 7. & In chloroquine-sensitive areas, pregnant women should use chloroquine as chemoprophylaxis. & A I \\
\hline 8. & $\begin{array}{l}\text { Where exposure to chloroquine-resistant falciparum malaria is unavoidable, pregnant women should } \\
\text { use mefloquine from conception through the first trimester (A II) and during the second and third } \\
\text { trimesters }(A I)(17-19) \text {. }\end{array}$ & A II, A I \\
\hline
\end{tabular}


9. $\quad$ There are no currently approved antimalarials for pregnant women travelling to mefloquine-resistant regions. Atovaquone-proguanil after the first trimester may be considered after careful discussion of the benefits and risks $(20,21)$.

10. Although safe in pregnancy, the combination of chloroquine and proguanil is inadequate as an antimalarial and cannot be recommended for chloroquine-resistant areas (22).

\section{Breastfeeding women}

\begin{tabular}{l|l|l}
\hline 11. & Infants should receive their own appropriate chemoprophylaxis even if breastfed (23). & A III \\
\hline 12. & Women breastfeeding a child $<5 \mathrm{~kg}$ should avoid atovaquone-proguanil (23). & $\mathrm{C} \mathrm{II}$ \\
\hline 13. & $\begin{array}{l}\text { Limited data suggest that doxycycline absorption through breast milk is negligible and that } \\
\text { breastfeeding is not an absolute contraindication to maternal use (23). }\end{array}$ & $\mathrm{C} \mathrm{III}$ \\
\hline
\end{tabular}

\begin{tabular}{|c|c|c|}
\hline \multicolumn{3}{|c|}{ Migrants } \\
\hline 14. & $\begin{array}{l}\text { For at least } 12 \text { months after migrants arrive in Canada, test for malaria in cases of unexplained } \\
\text { fever. }\end{array}$ & C III \\
\hline 15. & $\begin{array}{l}\text { Consider malaria screening in asymptomatic new arrivals from highly endemic areas, and treat } \\
\text { those who have parasitemia (apart from the presence of gametocytes only) in blood smears. }\end{array}$ & C III \\
\hline 16. & $\begin{array}{l}\text { Ask migrants from malaria-endemic countries about future travel plans. Doing so may provide the } \\
\text { opportunity for anticipatory guidance about malaria (25). }\end{array}$ & C III \\
\hline
\end{tabular}

\section{Long-term travellers or expatriates}

\begin{tabular}{|c|c|c|}
\hline 17. & $\begin{array}{l}\text { Guidelines for preventing malaria in long-term travellers or expatriates should not deviate } \\
\text { considerably from the recommendations for short-term travellers }(26) \text {. }\end{array}$ & B III \\
\hline 18. & Training long-term travellers in the use of rapid diagnostic tests is reasonable $(26,34)$. & C III \\
\hline 19. & $\begin{array}{l}\text { For long-term travellers who are more likely to buy drugs in countries without quality controls, } \\
\text { provide education about counterfeit antimalarial medications (35-37). }\end{array}$ & C II \\
\hline 20. & $\begin{array}{l}\text { Consider primaquine for terminal prophylaxis for military personnel, long-term travellers or } \\
\text { expatriates returned from regions with } P \text {. vivax transmission }(26,38,39) \text {. }\end{array}$ & A I \\
\hline \multicolumn{3}{|c|}{ Visiting friends and family (VFRs) } \\
\hline 21. & $\begin{array}{l}\text { Inform Canadian VFRs travelling to malaria-endemic countries about the risk of malaria, including } \\
\text { the loss of partial immunity from living in Canada and the increased risk of severe disease in } \\
\text { children and pregnant women (25). }\end{array}$ & C III \\
\hline 22. & $\begin{array}{l}\text { Counsel Canadian VFRs travelling to malaria-endemic countries about PPM (repellents, bed nets, } \\
\text { behavioural choices) and chemoprophylaxis }(25) .\end{array}$ & C III \\
\hline 23. & $\begin{array}{l}\text { Discuss the affordability of chemoprophylaxis with Canadian VFRs travelling to malaria-endemic } \\
\text { countries, taking cost into account in deciding about choices (25). }\end{array}$ & C III \\
\hline \multicolumn{3}{|c|}{ Travellers with co-morbidities } \\
\hline 24. & $\begin{array}{l}\text { Individuals who are immunosuppressed or have co-morbidities should consult with a travel medicine } \\
\text { or infectious disease expert (40). }\end{array}$ & B III \\
\hline 25. & $\begin{array}{l}\text { Potential drug interactions and overlapping toxicities warrant careful review before antimalarial drugs } \\
\text { are prescribed for people with chronic medical conditions, including HIV infection (41). }\end{array}$ & A I \\
\hline 26. & $\begin{array}{l}\text { HIV-infected individuals who are pregnant or have advanced immune suppression should be } \\
\text { encouraged to choose non-malaria endemic locations or defer travel until after pregnancy or } \\
\text { restoration of immune function. }\end{array}$ & B III \\
\hline 27. & $\begin{array}{l}\text { Provide standby antimalarial therapy for travellers with asplenia who may experience delays in } \\
\text { accessing appropriate care for febrile illness. }\end{array}$ & A II \\
\hline 28. & $\begin{array}{l}\text { A pre-travel trial with INR (international normalized ratio) testing should be done if mefloquine, } \\
\text { doxycycline or proguanil (including atovaquone-proguanil) are to be used by people taking warfarin }\end{array}$ & A II \\
\hline
\end{tabular}




\begin{tabular}{|c|c|c|}
\hline \multicolumn{2}{|c|}{ Recommendation } & \multirow{2}{*}{$\begin{array}{l}\text { EBM } \\
\text { rating* }\end{array}$} \\
\hline & (42-45). & \\
\hline 29. & Avoid chloroquine and mefloquine in the presence of a chronic seizure disorder. & E II \\
\hline 30. & Avoid chloroquine and mefloquine for travellers with myasthenia gravis. & E III \\
\hline 31. & $\begin{array}{l}\text { Carefully review mental health history before prescribing mefloquine to ensure that psychotic, } \\
\text { depressive or anxiety disorders are absent (46). }\end{array}$ & Al \\
\hline 32. & $\begin{array}{l}\text { Chloroquine may exacerbate psoriasis. Mefloquine, doxycycline and atovaquone-proguanil are } \\
\text { preferable to chloroquine in patients with underlying psoriasis. }\end{array}$ & B III \\
\hline 33. & Primaquine should not be used as chemoprophylaxis in the presence of G6PD deficiency. & E II \\
\hline 34. & $\begin{array}{l}\text { Atovaquone-proguanil may be the preferred choice for malaria prophylaxis in the presence of } \\
\text { porphyria. }\end{array}$ & B III \\
\hline & \multicolumn{2}{|c|}{$\begin{array}{l}\text { *EBM = Evidence-based medicine. The EBM ratings are as follows: } \\
\text { Strength of recommendation: } \\
\text { A = Good evidence to support a recommendation for use } \\
\text { B = Moderate evidence to support a recommendation for use } \\
\text { C = Poor evidence to support a recommendation for or against use } \\
\text { D = Moderate evidence to support a recommendation against use } \\
\text { E = Good evidence to support a recommendation against use } \\
\text { Quality of evidence: } \\
\text { I = Evidence from at least one properly randomized, controlled trial } \\
\text { II = Evidence from at least one well-designed clinical trial without randomization; from cohort or case-controlled } \\
\quad \text { analytic studies, preferably from more than one centre; from multiple time series; or from dramatic results in } \\
\quad \text { uncontrolled experiments } \\
\text { III = Evidence from opinions of respected authorities on the basis of clinical experience, descriptive studies or reports } \\
\quad \text { of expert committees. }\end{array}$} \\
\hline
\end{tabular}

\section{Long-term safety of chemoprophylaxis and PPM}

Long-term use of chemoprophylaxis recommended for short-stay travellers does not result in additional risk of severe adverse events although data on the effectiveness and tolerance of recommended regimens are limited. Table 2 summarizes the safety of chemoprophylaxis with long-term use.

\section{Table 2: Safety of chemoprophylaxis with long-term use}

\begin{tabular}{|l|l|}
\hline Chemoprophylactic drug & Effects of long-term use \\
\hline Chloroquine & $\begin{array}{l}\text { Requires an ophthalmologic examination at least every 2 years (30). However, } \\
\text { chloroquine is seldom indicated because of extensive drug resistance. }\end{array}$ \\
\hline Mefloquine & $\begin{array}{l}\text { Well tolerated (47-50). } \\
\text { Mefloquine tolerance improves over time, possibly because any adverse events } \\
\text { become apparent relatively early (47). Consequently, there does not appear to be } \\
\text { increased risk with long-term use (28). }\end{array}$ \\
\hline Atovaquone-proguanil & $\begin{array}{l}\text { Although data on prolonged use of atovaquone-proguanil are limited, the individual } \\
\text { components have been used for extended periods (30). }\end{array}$ \\
\hline Doxycycline & $\begin{array}{l}\text { Although data are limited, the drug and the related minocycline have been used for } \\
\text { extended periods for other indications (31). }\end{array}$ \\
\hline
\end{tabular}

Currently, no long-lasting, insecticide-treated nets are registered for use in Canada. Insecticide-treated bed nets can be obtained from some Canadian travel health clinics and other domestic and international suppliers (8):

- The insecticide in most bed nets starts to lose its effect after six months (8).

- Liquid permethrin used to treat bed nets is not available in Canada.

- Travellers should renew the insecticide treatment of their bed nets at the start of rainy seasons. 


\section{Counterfeit drugs}

Many expatriates and long-term travellers may have the opportunity to buy their antimalarial chemoprophylaxis and antimalarial drugs over the counter at local pharmacies where they are staying and cannot evaluate the authenticity of these drugs. Encourage all travellers and expatriates to buy a supply of medication in countries with strict quality control measures (35-37).

If travellers are buying outside of Canada bear in mind the following:

- Coartem ${ }^{\circledR}$ (artemether-lumefantrine) is not yet licensed for distribution in Canada but is recommended by the World Health Organization as first-line treatment for $P$. falciparum malaria. Travellers should buy it in Europe, the USA or other countries where counterfeiting is unlikely (39).

- Atovaquone-proguanil prophylaxis may be too expensive for most long-term use. Long-term travellers and expatriates may choose to purchase enough for one or two self-treatment courses (51).

\section{Rapid diagnostic tests}

Rapid diagnostic tests are essential diagnostic tools when malaria microscopy results are not available within two hours (26). Rapid diagnostic tests are simple to use, require no equipment or specialized laboratory skills and can be valuable adjuncts in diagnosing malaria (52). However, many travellers are unable to complete the procedures or interpret the results correctly $(26,53,54)$. Without adequate training of laboratory staff, the usefulness of Rapid diagnostic tests may be no better among expatriates $(34,55)$. Nevertheless, key members of a reasonably stable expatriate community could be trained in their use and in administration of appropriate selftreatment $(26,34)$.

\section{Standby emergency self-treatment}

Self-treatment is a temporary, life-saving measure for 24 hours while medical attention is sought. Travellers to high-risk regions should never rely exclusively on self-treatment $(40,56-58)$. Self-treatment regimens by region are summarized in Table 3.

Reasons for self-treatment include travelling/staying in these areas:

- Sub-Saharan Africa, where $90 \%$ of global malaria morbidity and mortality occurs.

- Remote regions where access to health care is a problem.

- Regions where malaria risk is small and self-treatment is preferable to long-term prophylaxis $(26,28,56,59)$.

Standby malaria treatment with atovaquone-proguanil or quinine and doxycycline is recommended for travellers who are more than a day away from malaria diagnostic help.

Table 3: Self-treatment regimens

\begin{tabular}{l|l}
\hline Region & Self-treatment regimens \\
\hline Chloroquine-sensitive regions & $\begin{array}{l}\text { Self-treat with chloroquine and then resume or start chloroquine } \\
\text { prophylaxis }(54,56,60) .\end{array}$ \\
\hline $\begin{array}{l}\text { Chloroquine-resistant and/or } \\
\text { chloroquine- and mefloquine-resistant }\end{array}$ & $\begin{array}{l}\text { Self-treat with a drug different from that used for prophylaxis: } \\
P . \text { falciparum regions }\end{array}$ \\
& a. Atovaquone-proguanil (Malarone $\left.{ }^{\circledR}\right)$ or \\
& b. oral quinine and doxycycline or \\
& artemether-lumefantrine (Coartem $\left.{ }^{\circledR}\right)$, purchased from a \\
& $\begin{array}{l}\text { country with high standards of quality control to minimize } \\
\text { the likelihood of being sold counterfeit products } \\
(36,37,54,60) .\end{array}$ \\
\hline
\end{tabular}

Some antimalarials are contraindicated for the treatment of malaria (self-treatment or otherwise):

- mefloquine $(61,62)$ 
- $\quad$ pyrimethamine-sulfadoxine (Fansidar) (63)

- mefloquine-Fansidar (62)

- halofantrine (39)

- chloroquine-Fansidar (59).

\section{Terminal prophylaxis}

$P$. vivax and $P$. ovale parasites can persist in the liver and cause relapses for as long as five years after the person has left a malaria-endemic area. Primaquine anti-relapse therapy (PART) decreases the risk of relapses by acting against the liver stages of $P$. vivax and $P$. ovale. PART is usually administered during or after the last two weeks of chemoprophylaxis to those who have been in malaria-endemic regions (most malarial areas of the world except Haiti and the Dominican Republic) $(26,38,39,64)$. Primaquine is contraindicated for use as PART in people with G6PD deficiencies, in pregnancy and in nursing mothers if the infant is G6PD deficient.

\section{Travellers with co-morbidities}

Interactions between malaria and other underlying medical conditions may result in increased susceptibility to and severity of malaria or complications of the underlying conditions. Some underlying health conditions may be exacerbated by or preclude using one or more antimalarial medications.

Routinely undertake a drug interaction check to avoid any potential adverse drug interactions unless the traveller's medications are known to be safely used with the proposed antimalarial agent.

\section{Immunocompromised hosts}

Immunocompromised travellers should carefully adhere to both PPM and chemoprophylaxis.

\section{HIV/AIDS}

There is a significant and complex interaction between human immunodeficiency virus (HIV) and $P$. falciparum. Assess for drug interactions, and consider the risk of overlapping adverse effect profiles (65). CATMAT recommends consulting with a travel/tropical medicine/infectious disease expert and the traveller's HIV specialist (40).

\section{Asplenia}

Asplenia increases the risk, magnitude and duration of parasitemia, even among partially immune individuals in malaria-endemic countries (41), and enhances the risk of severe and fatal malaria in travellers with this condition (66). Recommend standby self-treatment in addition to prophylactic measures if the traveller is heading to remote regions and/or access to care is limited. Since fever may be due to malaria or bacterial infection, provide antibacterial standby treatment (67).

\section{Other conditions}

A list of other conditions and their effects on the choice of malaria chemoprophylaxis are summarized in Table 4.

\section{Table 4: Other conditions that affect choice of malaria chemoprophylaxis}

\begin{tabular}{l|l}
\hline Condition & Impact on choice of malaria chemoprophylaxis \\
\hline $\begin{array}{l}\text { Abnormal } \\
\text { coagulation }\end{array}$ & $\begin{array}{l}\text { Mefloquine, doxycycline and proguanil may potentiate warfarin }(42-45,68) . \\
\text { Conduct a medication trial several weeks in advance of travel and International Normalized } \\
\text { Ratio (INR) serial testing to allow adjustment of the anticoagulant dose both before and after } \\
\text { travel. }\end{array}$ \\
\hline $\begin{array}{l}\text { Seizure } \\
\text { disorders }\end{array}$ & $\begin{array}{l}\text { Chloroquine and mefloquine may exacerbate seizures, so prescribe alternative agents. There } \\
\text { is no evidence that febrile seizures in children are a contraindication for these drugs. } \\
\text { Concurrent use of anticonvulsant drugs that induce hepatic microsomal enzymes (e.g. } \\
\text { barbiturates, phenytoin, carbamazepine) may decrease serum levels and the half-life of } \\
\text { doxycycline, and may require dosage adjustment (45). }\end{array}$ \\
\hline
\end{tabular}




\begin{tabular}{|c|c|}
\hline $\begin{array}{l}\text { Myasthenia } \\
\text { gravis }\end{array}$ & $\begin{array}{l}\text { Malaria infections may exacerbate myasthenia gravis. Optimal prevention through adherence } \\
\text { to chemoprophylaxis and PPMs should be reinforced. } \\
\text { Avoid chloroquine, mefloquine and doxycycline as they have been associated with worsening } \\
\text { of myasthenic symptoms. Doxycycline may be considered in stable patients, particularly for } \\
\text { those with only ophthalmologic symptoms, though CATMAT recommends a pre-travel therapy } \\
\text { trial. A pre-travel trial of atovaquone-proguanil therapy is recommended, since proguanil } \\
\text { monotherapy has been reported to worsen myasthenic symptoms (69). } \\
\text { Primaquine has not been associated with myasthenic symptoms and may be an option for } P \text {. } \\
\text { falciparum prophylaxis (after ruling out G6PD deficiency) in myasthenic travellers who are } \\
\text { unable to tolerate doxycycline and atovaquone-proguanil. }\end{array}$ \\
\hline $\begin{array}{l}\text { Psychiatric } \\
\text { disorders }\end{array}$ & $\begin{array}{l}\text { Assess for history of depression, generalized anxiety disorder or psychosis before prescribing } \\
\text { mefloquine }(46,70) \text {. } \\
\text { Dose-related neuropsychiatric adverse effects are well recognized with mefloquine and to a } \\
\text { lesser extent with chloroquine }(71,72) \text {. }\end{array}$ \\
\hline $\begin{array}{l}\text { Hepatic or } \\
\text { renal } \\
\text { dysfunction }\end{array}$ & $\begin{array}{l}\text { Moderate to severe hepatic or renal dysfunction may alter antimalarial medication levels. }{ }^{*} \text { If } \\
\text { necessary, consult with a travel/tropical medicine expert. } \\
\text { Severe renal insufficiency (creatinine clearance }<30 \mathrm{~mL} / \mathrm{min} \text { ) is a contraindication to } \\
\text { atovaquone-proguanil use. }\end{array}$ \\
\hline Psoriasis & Avoid chloroquine as it may trigger acute flares of psoriasis $(73,74)$. \\
\hline $\begin{array}{l}\text { Glucose-6- } \\
\text { phosphate } \\
\text { dehydrogenase } \\
\text { (G6PD) } \\
\text { deficiency }\end{array}$ & $\begin{array}{l}\text { Primaquine is associated with a potentially life-threatening risk of hemolysis. Although G-6PD } \\
\text { deficiency is raised as a concern by the manufacturers of chloroquine, experts do not consider } \\
\text { this a contraindication, since significant hemolysis is unlikely at prophylactic doses. }\end{array}$ \\
\hline Porphyria & $\begin{array}{l}\text { Apart from atovaquone-proguanil ( } 75) \text {, all the first-line malaria chemoprophylactic agents may } \\
\text { be porphyrinogenic. Use with caution. }\end{array}$ \\
\hline
\end{tabular}

\section{Conclusion}

Special groups of travellers require additional information for prevention and management of malaria. In addition, they should recognize the importance of adherence to recommendations for chemoprophylaxis and PPM. Treatment varies according to the species of Plasmodium, the severity of disease and the region where the malaria was acquired, as well as potential interactions between chronic medications and recommended antimalarial therapy.

\section{Acknowledgements}

CATMAT acknowledges and appreciates the contribution of Joanna Odrowaz and Elspeth Payne to the development of the summaries and Manisha Kulkarni for her contribution to the statement.

CATMAT Members: Boggild A, Brophy J, Bui YG, Crockett M, Ghesquiere W, Greenaway C, Henteleff A, Libman M, Teitelbaum P and McCarthy A (Chair).

Liaison members: Hui C (Canadian Paediatric Society) and Gershman M (US Centers for Disease Control and Prevention).

Ex-officio members: Marion D (Canadian Forces Health Services Centre, Department of National Defence), McDonald P (Division of Anti-Infective Drugs, Health Canada), Schofield S (Directorate of Force Health Protection, Department of National Defence) and Tepper M (Directorate of Force Health Protection, Department of National Defence).

Member Emeritus: Jeanes CWL. 


\section{Conflict of interest}

There are no conflicts of interest to declare.

\section{Funding}

This work was supported by the Public Health Agency of Canada.

\section{References}

(1) McCarthy AE, Plourde P, Kuhn S, Bodie M. Parenteral quinine for severe malaria: Five year surveillance data from the Canadian Malaria Network. 10th Conference of the International Society of Travel Medicine 2007; Abstract No. FC02.01.

(2) Committee to Advise on Tropical Medicine and Travel. Canadian Recommendations for the Prevention and Treatment of Malaria (in press). http://publications.gc.ca/site/eng/463465/publication.html

(3) Boggild A, Brophy J, Charlebois P, Crockett M, Geduld J, Ghesquiere W, et al. Summary of recommendations for the prevention of malaria by the Committee to Advise on Tropical Medicine and Travel (CATMAT). CCDR 2014;40(7):118.

(4) Boggild A, Brophy J, Charlebois P, Crockett M, Geduld J, Ghesquiere W, et al. Summary of recommendations for the diagnosis and treatment of malaria by the Committee to Advise on Tropical Medicine and Travel

(CATMAT). Can Comm Dis Rep 2014;40(7):131.

(5) Maitland K. M, K. Pathophysiology of severe malaria in children. Acta Trop 2004;90(2):131.

(6) American Academy of Pediatrics editor. Red Book: 2009 Report of the Committee on Infectious Diseases. 28th ed. Illinois: American Academy of Pediatrics; 2009.

(7) Fradin MS, Day JF. Comparative Efficacy of Insect Repellents against Mosquito Bites. N Engl J Med 2002 07/04; 2014/02;347(1):13-18.

(8) Committee to Advise on Tropical Medical and Travel. Statement on personal protective measures to prevent arthropod bites. Canadian Communicable Disease Report 2012;38(ASC-3):1-18.

(9) Centers for Disease Control and Prevention. Information for health care providers: preventing malaria in infants and children. 2006; Available at: http://wwwnc.cdc.gov/travel.

(10) Camus D, Djossou F, Schilthuis HJ, Hogh B, Dutoit E. Atovaquone-proganil versus chloroquine-proguanil for malaria prophylaxis in nonimmune pediatric travelers: results of an international, randomized, open-label study. Clin Infect Dis 2004;38(12):1716-1723.

(11) Pang LW, Limsomwong N, Boudreau EF, Singharaj P. Doxycycline prophylaxis for falciparum malaria. Lancet 1987;329(8543):1161-1164.

(12) Overbosch D, Schilthuis H, Bienzle U, Behrens RH, Kain KC, Clarke PD, et al. Atovaquone-Proguanil versus Mefloquine for Malaria Prophylaxis in Nonimmune Travelers: Results from a Randomized, Double-Blind Study. Clinical Infectious Diseases 2001 October 01;33(7):1015-1021.

(13) Weiss W, Oloo A, Johnson A, Koech D, Hoffman S. Daily primaquine is effective for prophylaxis against falciparum malaria in Kenya: comparison with mefloquine, doxycycline, and chloroquine plus proguanil. J Infectious Dis 1995;171(6):1569-75.

(14) Martindale editor. The Complete Drug Reference. 32nd ed. London: Pharmaceutical Press; 2008. 
(15) Shulman CE, Dorman EK. Importance and prevention of malaria in pregnancy. Trans R Soc Trop Med Hyg 2003 0;97(1):30-35.

(16) McGready R, Hamilton K, Simpson JA, Cho J, Luxemberger C, Edwards R, et al. Safety of the insect repellent N,N-dietyl-M-toluide (DEET) in pregnancy. Am J Trop Med Hyg 2001;65(4):285-289.

(17) Nosten F, Vincenti M, Simpson J, Yei P, Thwai KL, Vries Ad, et al. The Effects of Mefloquine Treatment in Pregnancy. Clin Infect Dis 1999 Apr.;28(4):808-815.

(18) Balocco R, Bonati M. Melfoquine prophylaxis against malaria for female travelers of childbearing age. Lancet 1992;340(8814):309-310.

(19) Steketee RW, Wirima JJ, Slutsker L, Roberts JM, Khoromana CO, Heymann DL, et al. Malaria parasite infection during pregnancy and at delivery in mother, placenta, and newborn: efficacy of chloroquine and mefloquine in rural Malawi. The American Journal of Tropical Medicine and Hygiene 1996 July 01;55(1 Suppl):24-32.

(20) Stauffer WM, Kamat D, Magill AJ. Traveling with Infants and Children. Part IV: Insect Avoidance and Malaria Prevention. Journal of Travel Medicine 2003;10(4):225-240.

(21) Na-Bangchang K, Manyando C, Ruengweerayut R, Kioy D, Mulenga M, Miller G, et al. The pharmacokinetics and pharmacodynamics of atovaquone and proguanil for the treatment of uncomplicated falciparum malaria in third-trimester pregnant women. Eur J Clin Pharmacol 2005 Sep;61(8):573-582.

(22) Hogh B, Clarke PD, Camus D, Nothdurft HD, Overbosch D, Gunther M, et al. Atovaquone-proguanil versus chloroquine-proguanil for malaria prophylaxis in non-immune travellers: a randomised, double-blind study. Malarone International Study Team. Lancet 2000 Dec 2;356(9245):1888-1894.

(23) American Academy of Pediatrics Committee on Drugs. Transfer of drugs and other chemicals into human milk. Pediatrics 2001 Sep;108(3):776-789.

(24) Mali S, Kachur SP, Arguin PM, Division of Parasitic Diseases and Malaria, Center for Global Health, Centers for Disease Control and Prevention (CDC). Malaria surveillance--United States, 2010. MMWR Surveill Summ 2012 Mar 2;61(2):1-17.

(25) Bacaner N, Stauffer B, Boulware DR, Walker PF, Keystone JS. Travel medicine considerations for North American immigrants visiting friends and relatives. JAMA 2004 Jun 16;291(23):2856-2864.

(26) Chen LH, Wilson ME, Schlagenhauf P. Prevention of malaria in long-term travelers. JAMA 2006 Nov 8;296(18):2234-2244.

(27) Berg J, Visser LG. Expatriate chemoprophylaxis use and compliance: past, present and future from an occupational health perspective. J Travel Med 2007 Sep-Oct;14(5):357-358.

(28) Schlagenhauf P, Petersen E. Malaria chemoprophylaxis: strategies for risk groups. Clin Microbiol Rev 2008 Jul;21(3):466-472.

(29) Korhonen C, Peterson K, Bruder C, Jung P. Self-reported adverse events associated with antimalarial chemoprophylaxis in peace corps volunteers. Am J Prev Med 2007 Sep;33(3):194-199.

(30) Schlagenhauf P, Tschopp A, Johnson R, Nothdurft HD, Beck B, Schwartz E, et al. Tolerability of malaria chemoprophylaxis in non-immune travellers to sub-Saharan Africa: multicentre, randomised, double blind, four arm study. BMJ 2003 Nov 8;327(7423):1078.

(31) Knobloch J. Long-term malaria prophylaxis for travelers. J Travel Med 2004 Nov-Dec;11(6):374-378. 
(32) Hamer DH, Ruffing R, Callahan MV, Lyons SH, Abdullah AS. Knowledge and use of measures to reduce health risks by corporate expatriate employees in western Ghana. J Travel Med 2008 Jul-Aug;15(4):237-242.

(33) Dahlgren AL, Deroo L, Avril J, Bise G, Loutan L. Health risks and risk-taking behaviors among International Committee of the Red Cross (ICRC) expatriates returning from humanitarian missions. J Travel Med 2009 NovDec;16(6):382-390.

(34) Funk M, Schlagenhauf P, Tschopp A, Steffen R. MalaQuick versus ParaSight F as a diagnostic aid in travellers' malaria. Trans R Soc Trop Med Hyg 1999 May-Jun;93(3):268-272.

(35) Dondorp AM, Newton PN, Mayxay M, Van Damme W, Smithuis FM, Yeung S, et al. Fake antimalarials in Southeast Asia are a major impediment to malaria control: multinational cross-sectional survey on the prevalence of fake antimalarials. Trop Med Int Health 2004 Dec;9(12):1241-1246.

(36) Newton P, Proux S, Green M, Smithuis F, Rozendaal J, Prakongpan S, et al. Fake artesunate in southeast Asia. Lancet 2001 Jun 16;357(9272):1948-1950.

(37) Cockburn R, Newton PN, Agyarko EK, Akunyili D, White NJ. The global threat of counterfeit drugs: why industry and governments must communicate the dangers. PLoS Med 2005 Apr;2(4):e100.

(38) Kotwal RS, Wenzel RB, Sterling RA, Porter WD, Jordan NN, Petruccelli BP. An outbreak of malaria in US Army Rangers returning from Afghanistan. JAMA 2005 Jan 12;293(2):212-216.

(39) World Health Organization. Guidelines for the treatment of malaria, Second edition. 2010.

(40) Centers for Disease Control and Prevention (CDC). CDC Health Information for International Travel $2012<\mathrm{br}$ />. New York: Oxford University Press; 2012.

(41) Bach O, Baier M, Pullwitt A, Fosiko N, Chagaluka G, Kalima M, et al. Falciparum malaria after splenectomy: a prospective controlled study of 33 previously splenectomized Malawian adults. Trans R Soc Trop Med Hyg 2005 Nov;99(11):861-867.

(42) Westfall LK, Mintzer DL, Wiser TH. Potentiation of warfarin by tetracycline. Am J Hosp Pharm 1980 Dec;37(12):1620, 1625.

(43) Loefler I. Mefloquine and anticoagulant interaction. J Travel Med 2003 May-Jun;10(3):194-195.

(44) Armstrong G, Bed MF, Scahill S. Warfarin potentiated by proguanil. BMJ 1991 Sep 28;303(6805):789.

(45) Doxycycline: Cautions (Drug Interactions). 2007;Report No.:10-4-0007.

(46) Schlagenhauf P. Mefloquine for malaria chemoprophylaxis 1992-1998: a review. J Travel Med 1999 Jun;6(2):122-133.

(47) Lobel HO, Varma JK, Miani M, Green M, Todd GD, Grady K, et al. Monitoring for mefloquine-resistant Plasmodium falciparum in Africa: implications for travelers' health. Am J Trop Med Hyg 1998 Jul;59(1):129-132.

(48) Lobel HO, Bernard KW, Williams SL, Hightower AW, Patchen LC, Campbell CC. Effectiveness and tolerance of long-term malaria prophylaxis with mefloquine. Need for a better dosing regimen. JAMA 1991 Jan 16;265(3):361-364.

(49) Lobel HO, Miani M, Eng T, Bernard KW, Hightower AW, Campbell CC. Long-term malaria prophylaxis with weekly mefloquine. Lancet 1993 Apr 3;341(8849):848-851.

(50) Ohrt C, Richie T, Widjaja H, Shanks G, Fitriadi J, Fryauff D, et al. Mefloquine compared with doxycycline for the prophylaxis of malaria in Indonesian soldiers. A randomized, double-blind, placebo-controlled trial. Ann Intern Med 1997;126(12):963-72. 
(51) Kain KC, MacPherson DW, Kelton T, Keystone JS, Mendelson J, MacLean JD. Malaria deaths in visitors to Canada and in Canadian travellers: a case series. Canadian Medical Association Journal 2001 March 06;164(5):654-659.

(52) Marx A, Pewsner D, Egger M, Nuesch R, Bucher HC, Genton B, et al. Meta-analysis: accuracy of rapid tests for malaria in travelers returning from endemic areas. Ann Intern Med 2005 May 17;142(10):836-846.

(53) Jelinek T, Amsler L, Grobusch MP, Nothdurft HD. Self-use of rapid tests for malaria diagnosis by tourists. Lancet 1999 Nov 6;354(9190):1609.

(54) Schlagenhauf P, Steffen R. Stand-by treatment of malaria in travellers: a review. J Trop Med Hyg 1994 Jun;97(3):151-160.

(55) Schlagenhauf P, Steffen R, Tschopp A, Van Damme P, Mittelholzer ML, Leuenberger $\mathrm{H}$, et al. Behavioural aspects of travellers in their use of malaria presumptive treatment. Bull World Health Organ 1995;73(2):215221.

(56) Schlagenhauf P, Petersen E. Standby emergency treatment of malaria in travelers: experience to date and new developments. Expert Rev Anti Infect Ther 2012 May;10(5):537-546.

(57) Swales CA, Chiodini PL, Bannister BA, Health Protection Agency Advisory Committee on Malaria Prevention in UK Travellers. New guidelines on malaria prevention: A summary. J Infect 2007 Feb;54(2):107-110.

(58) Quach C, Kain K, MacPherson D, Mendelson J, MacLean J. Malaria deaths in Canadian travellers. Can Commun Dis Rep 1999 Mar 15;25(6):50-53.

(59) Chen LH, Wilson ME, Schlagenhauf P. Controversies and misconceptions in malaria chemoprophylaxis for travelers. JAMA 2007 May 23;297(20):2251-2263.

(60) Nothdurft HD, Jelinek T, Pechel SM, Hess F, Maiwald H, Marschang A, et al. Stand-by treatment of suspected malaria in travellers. Trop Med Parasitol 1995 Sep;46(3):161-163.

(61) Weinke T, Trautmann M, Held T, Weber G, Eichenlaub D, Fleischer K, et al. Neuropsychiatric side effects after the use of mefloquine. Am J Trop Med Hyg 1991 Jul;45(1):86-91.

(62) Luxemburger C, Price RN, Nosten F, Ter Kuile FO, Chongsuphajaisiddhi T, White NJ. Mefloquine in infants and young children. Ann Trop Paediatr 1996 Dec;16(4):281-286.

(63) Roll Back Malaria Department WHOU. World Malaria Report. 2005.

(64) Hill DR, Baird JK, Parise ME, Lewis LS, Ryan ET, Magill AJ. Primaquine: report from CDC expert meeting on malaria chemoprophylaxis I. Am J Trop Med Hyg 2006 Sep;75(3):402-415.

(65) Khoo S, Back D, Winstanley P. The potential for interactions between antimalarial and antiretroviral drugs. AIDS 2005 Jul 1;19(10):995-1005.

(66) Demar M, Legrand E, Hommel D, Esterre P, Carme B. Plasmodium falciparum malaria in splenectomized patients: two case reports in French Guiana and a literature review. Am J Trop Med Hyg 2004 Sep;71(3):290-293.

(67) Baker H. The influence of chloroquine and related drugs on psoriasis and keratoderma. Br J Dermatol 1966;78:161.

(68) Touze JE, Heno P, Fourcade L, Deharo JC, Thomas G, Bohan S, et al. The effects of antimalarial drugs on ventricular repolarization. Am J Trop Med Hyg 2002 Jul;67(1):54-60.

(69) Fischer PR, Walker E. Myasthenia and malaria medicines. J Travel Med 2002 Sep-Oct;9(5):267-268. 
(70) Schlagenhauf P, Adamcova M, Regep L, Schaerer MT, Rhein HG. The position of mefloquine as a 21st century malaria chemoprophylaxis. Malar J 2010 Dec 9;9:357-2875-9-357.

(71) Barrett PJ, Emmins PD, Clarke PD, Bradley DJ. Comparison of adverse events associated with use of mefloquine and combination of chloroquine and proguanil as antimalarial prophylaxis: postal and telephone survey of travellers. BMJ 1996 Aug 31;313(7056):525-528.

(72) Akhtar S, Mukherjee S. Chloroquine induced mania. Int J Psychiatry Med 1993;23(4):349-356.

(73) Kuflik EG. Effect of antimalarial drugs on psoriasis. Cutis 1980 Aug;26(2):153-155.

(74) Fry L, Baker BS. Triggering psoriasis: the role of infections and medications. Clin Dermatol 2007 NovDec;25(6):606-615.

(75) The Drug Database for Acute Porphyria http://www.drugs-porphyria.org/monograph.php?id=4079. 